\section{Propofol in patients with cardiac disease}

Propofol is an intravenous anaesthetic which is chemically unrelated to other iv anaesthetics. Most anaesthetists are now becoming familiar with propofol's pharmacokinetic and pharmacodynamic properties. It has proved to be a reliable drug that can be used safely for induction and maintenance of anaesthesia for most surgical procedures and unlike other anaesthetic agents, it can especially be extended into the postoperative setting or intensive care unit for sedation. Propofol's greatest attributes are its pharmacokinetic properties which result in a rapid, clear emergence and lack of cumulative effects even after prolonged administration. Compared with other iv anaesthetics, the induction dose of propofol has a relatively higher incidence of respiratory depression, short-lived apnoea and blood pressure reduction that may occasionally be marked. Passible mechanisms for the hypotension may relate to (1) its action on peripheral vasculature (vasodilatation), (2) decreased myocardial contractility, (3) resetting of the baroreflex activity and (4) inhibition of the sympathetic nervous system outflow. In vitro studies indicate that propofol depresses the immunological reaction to bacterial challenge as well as the chemotactic activity. Clinical studies, in cardiac surgery, have demonstrated that propofol, in association with an opioid, is a logical anaesthetic choice. Propofol is about to receive approval for continuous $i v$ sedation. Comparative studies of propofol and midazolam have clearly demonstrated the superiority of propofol in terms of rapid recovery and precise control of the level of sedation.

Le propofol est un nouvel agent anesthésique iv qui se distingue des autres agents par sa structure chimique. Les anesthésistes sont maintenant familiers avec les propriétés pharmacocinétiques et pharmacodynamiques du propofol. Il s'est révélé efficace

\section{Key words}

ANAESTHESIA: cardiac;

ANAESTHETICS, INTRAVENOUS: propofol; PHARMACOLOGY.

From the Department of Anaesthesia, Montreal Heart Institute, 5000 Belanger Street East, Montreal, Quebec, Canada H1T 1C8.

Address correspondence to: Dr. Norman Searle, Department of Anaesthesia, Montreal Heart Institute, 5000 Belanger Street

East, Montreal, Quebec, Canada HIT $1 \mathrm{C} 8$.

Accepted for publication 3rd April, 1993.
Norman R. Searle MSc MDCM FRCPC, Philippe Sahab MD FRCPC et sécuritaire comme agent d'induction et de maintien de l'anesthésie pour diverses procédures chirurgicales. Contrairement aux autres anesthésiques iv, le propofol peut être retenu comme agent de sédation en période postopératoire ou pour faciliter la ventilation mécanique aux soins intensifs. Ses atouts principaux relèvent de ses propriétés pharmacocinétiques qui expliquent sa rapidité d'émergence et l'absence d'accumulation même à la suite d'une administration prolongée. En contrepartie, le propofol occasionne une plus grande incidence de dépression respiratoire, d'apnée et une chute de la tension artérielle qui, occasionnellement, peut être sévère. Les mécanismes probables pour expliquer cette chute de tension sont: 1) la vasodilatation périphérique (diminution des résistances périphériques), 2) la diminution de la contractilité myocardique, 3) un réajustement de l'activité des barorécepteurs et 4) une inhibition du système nerveux sympathique. Une dépression du système immunitaire peut se manifester à la suite d'une infusion prolongée. Des études in vitro suggèrent une dépression de la réponse immunologique ainsi qu'une diminution de la réponse chémotactique des leucocytes. Des études cliniques chez des patients subissant une chirurgie cardiaque ont démontré que le propofol, en association avec un opiacé, est une alternative anesthésique acceptable. Le propofol va recevoir l'approbation pour l'administration intraveineuse continue à visée sédative. Des études comparatives entre le propofol et le midazolam ont démontré la supériorité du propofol en termes de rapidité de récupération de l'anesthésie et du contrôle précis du niveau de sédation.

\section{Contents}

Pharmacokinetics of propofol

- Single bolus administration

- Repeated boluses or constant infusion

Pharmacodynamics

- Haemodynamic effects

- Peripheral vasodilatation

- Myocardial contractility

- Baroreflex activity

- Myocardial metabolism and blood flow

- Electrophysiological action of propofol

- Cerebral physiology and metabolism

- Respiration

- Premedication and dose of propofol

- Speed of injection 
- Oxygen-free radical scavenging

- The immune system

- Coagulation

- Allergic reactions

Clinical use of propofol in specific settings

- Cardiac anaesthesia

- Sedation in intensive care

- Cardioversion

Summary

In 1990, a new intravenous anaesthetic unrelated to the barbiturates or other anaesthetic induction agents was approved for clinical use in Canada. Its chemical structure is 2,6-diisopropylphenol, propofol or Diprivan (Figure 1). The North American experience with propofol is relatively short, even though it was first used as an induction agent in 1977. Within a few years, propofol created enormous interest because of its pharmacokinetic characteristics and clinical effects.

The drug is virtually insoluble in aqueous solutions. It was initially formulated as a $1 \%$ solution in $15 \%$ Cremophor EL. Unfortunately, the solvent caused a high incidence of pain on injection and was implicated in several hypersensitivity reactions. Reintroduction of propofol awaited the development of a lecithin-containing formulation. Presently, it is formulated as a $1 \%$ weight/volume in an emulsion of $10 \%$ soya bean oil, $2.25 \%$ glycerol and $1.2 \%$ purified egg phosphatide.

Studies with the new emulsion have shown several advantages over existing induction agents. The most interesting property is the ease of titration by continuous infusion for the maintenance of general anaesthesia or sedation. While anaesthetists' interest grew, clinical trials using propofol infusions were extended to patients in the

\footnotetext{
GLOSSARY

Brain retraction pressure (BRP)

Cardiac index (CI)

Cardiopulmonary bypass (CPB)

Central volume $(\mathrm{Vc})$

Cerebral spinal fluid pressure (CSFP)

Cerebral perfusion pressure (CPP)

Cerebral blood flow (CBF)

Cerebrovascular resistance (CVR)

Coronary artery bypass surgery (CABG)

Intensive care unit (ICU)

Intracranial pressure (ICP)

Systemic vascular resistance (SVR)

Volume of distribution (Vd)
}

extremes of age as well as in various pathophysiological states (i.e, cardiac, hepatic and renal dysfunction). This review will summarize the current pharmacokinetic and pharmacodynamic behaviour of propofol and then will focus on specific areas of clinical use such as: (1) cardiac anaesthesia, (2) sedation in the intensive care unit (ICU) and postoperative care. The clinical use of propofol in general surgery and in other specific settings has been reviewed by others. ${ }^{1,2}$

\section{Pharmacokinetics of propofol}

\section{Single bolus administration}

The mean standard induction dose in $95 \%$ of unpremedicated ASA I and II patients is $2.5 \mathrm{mg} \cdot \mathrm{kg}^{-1}$. Induction time, measured by loss of the eyelash reflex, varied from 22 to $125 \mathrm{sec}$. Following a single bolus injection of propofol, blood concentrations of propofol decline rapidly due to extensive redistribution ${ }^{3}$ (Figure 2). Kinetic data from several studies in volunteers, ASA I and II patients, elderly patients, hepatic and renal impaired patients are best described by an open three-compartment model: (1) rapid distribution of propofol from blood into highly perfused tissues such as brain, heart, lungs and liver $\left(t_{1 / 2 \alpha}\right.$ 1.8-4.1 $\mathrm{min}$ ), (2) redistribution and metabolic clearance of propofol ( $\mathrm{t}_{\mathrm{t} / 2 \beta}$ 21-69 $\mathrm{min}$ ) and (3) slow return of the lipophilic drug from more poorly perfused tissue to blood $\left.\left(t_{1 / 2 \gamma} 184-834 \mathrm{~min}\right)\right)^{4-7}$

Following the administration of a single bolus of 2.5 $\mathrm{mg} \cdot \mathrm{kg}^{-1}$ the mean central volume $(\mathrm{Vc})$ ranges from 22 to $41 \mathrm{~L}$, while the mean apparent volume of distribution (Vd) of 387 to $771 \mathrm{~L}$ is much larger. This high Vd reflects the high octanol/water partition coefficient while the high plasma protein binding (97-99\%) may explain the large Vc. Large discrepancies in volumes are to be expected with a lipophilic drug. Campbell et al. ${ }^{8}$ showed in three patients in whom the sampling period exceeded $42 \mathrm{hr}$ apparent elimination half-life ( $55.6 \mathrm{hr}$ ) and apparent volume of distribution $(1370 \mathrm{~L})$ greatly exceeding previously published estimates. This suggests that previous estimates were biased by the relatively short duration of blood sampling (i.e, 8-12 hr). This prolonged terminal half-life probably represents the rate of drug efflux from the peripheral lipid stores. The clinical implications of these observations are not as important for bolus administration as for prolonged infusion (i.e., $>8 \mathrm{hr}$ ).

The total body clearance following a single bolus of propofol varies between 1.3 to $2.2 \mathrm{~L} \cdot \mathrm{min}^{-1}$. This high clearance rate far exceeds liver blood flow, suggesting that extrahepatic and/or extrarenal metabolism (possibly in the lung) may contribute to the elimination of propofol. 5,9 
<smiles>CCCC1(CC)C(=O)NC(=S)NC1=O</smiles><smiles>C/C=C/CC1(C(C)CCC)CNC(=S)NC1=O</smiles>

Thiopentone

Thiamylal<smiles>C=CCC1(C(C)C=CC)C(=O)NC(=O)N(C)C1=O</smiles><smiles>CCOC(=O)c1cncn1C(C)c1ccccc1</smiles><smiles>CNC1CCCCC1=O</smiles>

Etomidate<smiles></smiles>
Midazolam

FIGURE 1 Structural formulae of different intravenous anaesthetic agents.

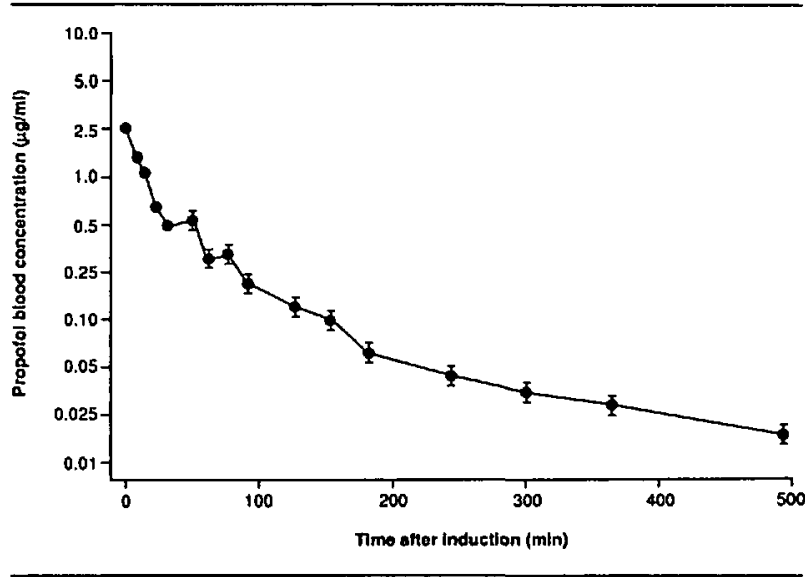

FIGURE 2 Mean blood propofol concentrations following induction doses of $2.5 \mathrm{mg} \cdot \mathrm{kg}^{-1}$ in six normal female patients. ${ }^{3}$
Comparing male with female patients, Kay et al. ${ }^{6}$ was unable to demonstrate any difference in $\mathrm{Vd}$ and clearance while White ${ }^{9}$ found an increase in clearance counterbalanced by an increase in the Vd in women. In the former study, the ratio of the steady-state volume of distribution to Vd during the elimination phase was lower in women than in men. This difference was attributed to a possible retention of propofol in poorly perfused fat deposits.

The effect of liver cirrhosis on propofol pharmacokinetics indicates that even in patients with reduced hepatic metabolism, the clearance of propofol from blood is similar to that of normal patients. ${ }^{10}$ As stated previously, extrahepatic mechanisms may be involved in propofol metabolism and these mechanisms may play an important role in the cirrhotic patient and during the anhepatic phase of orthotopic liver transplantation. ${ }^{11}$

Renal impairment does not appear to modify propofol pharmacokinetics. This issue has been addressed in uraemic patients undergoing either major abdominal surgery or renal transplantation. Indeed, after single bolus administration, no important pharmacokinetic differences were found between uraemic and normal subjects. ${ }^{12,13}$

Acute isovolumic haemodilution (average haematocrit $32.3 \%$ ) did not affect propofol pharmacokinetic behaviour in eight men undergoing prostatectomy except for an increase of $27 \%$ in the $\mathrm{Vc} .{ }^{14}$ The authors concluded that the induction dose of propofol following isovolumic haemodilution does not require modification.

Aging is known to influence the pharmacokinetics of barbiturates (thiopentone and methohexitone) and etomidate. Also, in elderly patients there is a tendency for total body water, cardiac output and hepatic blood flow to be less than in young patients. ${ }^{15}$ In 12 elderly patients (aged 65 to $80 \mathrm{yr}$ ), Kirkpatrick et al..$^{7}$ found a lower clearance rate and smaller $\mathrm{Vc}$ than in younger control patients (aged 18 to $35 \mathrm{yr}$ ), while the plasma protein binding of propofol and $\mathrm{Vd}$ were similar in both groups. This reduction in clearance suggests that metabolism of propofol is diminished in the elderly, possibly as a result of the reduction in the hepatic blood flow and/or cardiac output that occur with aging. Thus, a lower induction dose and a slower maintenance rate of administration are suggested in the elderly to avoid the haemodynamic and respiratory effects.

Concurrent drug administration such as fentanyl (100 $\mu \mathrm{g})$ prior to induction of anaesthesia increased the blood concentration of propofol and reduced the $\mathrm{Vd}^{5}$ This higher plasma propofol concentration may be related to either competitive metabolism between propofol and fentanyl or a reduction in the total blood supply to the liver. More recent studies have shown no difference in the pharmacokinetic profile when fentanyl was administered five minutes before induction ${ }^{16}$ and also with alfenta- 
nil infusion. ${ }^{17}$ The use of inhalational agents on the kinetics of a single bolus injection of propofol (2.5 $\mathrm{mg} \cdot \mathrm{kg}^{-1}$ ) reduced the elimination phase $(36 \%)$, Vd $(16 \%), \mathrm{t}_{1 / 2 \beta}(24 \%)$ and $\mathrm{t}_{1 / 2 \gamma}(35 \%){ }^{5}$

When a subanaesthetic dose of ${ }^{14} \mathrm{C}$-labelled propofol was given iv to male volunteers, $88 \%$ of the administered radioactivity was recovered in the urine, while less than $2 \%$ was excreted in the faeces. ${ }^{18}$ Metabolites of propofol are the 1 and 4 glucuronide and/or 4 sulphate conjugates. Metabolism of propofol is rapid since $81 \%$ of the radioactivity is found in the metabolites of propofol after $30 \mathrm{~min}$.

Emergence from anaesthesia after a single bolus injection (200 mg) in volunteers occurred in about ten minutes corresponding to a mean blood propofol concentration of $1.1 \mu \mathrm{g} \cdot \mathrm{ml}^{-1} .^{19}$ Similarly emergence from anaesthesia from single bolus injection, repeated bolus administration or a continuous intravenous infusion of propofol occurred at the same average plasma concentration of $1.0 \mu \mathrm{g} \cdot \mathrm{ml}^{-1}$ while complete orientation of patients was achieved at a plasma concentration of 0.5 $\mu \mathrm{g} \cdot \mathrm{ml}^{-1} .{ }^{9,20,21}$ Plasma propofol concentrations for emergence and complete orientation were independent of age, sex, and type or length of the surgical procedure.

\section{Repeated boluses or constant infusion}

Given the pharmacokinetic profile of propofol, a rational approach to its administration for the maintenance of anaesthesia would be a continuous infusion to minimize the peaks and valleys in its blood concentrations without significant accumulation. Knell and McKean ${ }^{20}$ showed that repeated propofol boluses of $1 \mathrm{mg} \cdot \mathrm{kg}^{-1}$ every six minutes for $75 \mathrm{~min}$ following an induction dose of 2.5 $\mathrm{mg} \cdot \mathrm{kg}^{-1}$, in patients with spinal anaesthesia, showed little or no accumulation in propofol blood concentration.

Pharmacokinetic indices derived during three constant infusion rates $\left(3,6\right.$ and $\left.9 \mathrm{mg} \cdot \mathrm{kg}^{-1} \cdot \mathrm{hr}^{-1}\right)$ for patients undergoing surgery with regional anaesthesia agreed with those reported during single bolus dose administration and demonstrated that the pharmacokinetics of propofol were linear over the range of the infusion rates studied. ${ }^{4}$

The pharmacokinetics of propofol, administered by infusion at a constant rate of $6 \mathrm{mg} \cdot \mathrm{kg}^{-1} \cdot \mathrm{hr}^{-1}$, were not affected by an infusion of alfentanil to achieve a plasma concentration of $30 \mathrm{ng} \cdot \mathrm{ml}^{-1} .{ }^{17}$ However, in this study the plasma alfentanil concentration was higher than expected for the infusion rate which was derived from previous pharmacokinetic data. It appears that propofol may affect the disposition kinetics of alfentanil by either decreasing the $\mathrm{Vd}$ and/or decreasing elimination but more studies are needed to clarify this.
In ten patients undergoing hypothermic $\mathrm{CPB}$, Massey et $a l^{22}$ found that clearance, $\mathrm{Vd}$ and terminal half-life were similar to those found in non-cardiac patients. A concentration of $>1 \mu \mathrm{g} \cdot \mathrm{ml}^{-1}$ was achieved within 15 min of starting the infusion $\left(4 \mathrm{mg} \cdot \mathrm{kg}^{-1} \cdot \mathrm{hr}^{-1}\right)$ and remained constant throughout surgery. Russell et al. ${ }^{23}$ though reported a decreased plasma propofol concentration at the onset of CPB with a gradual rise in propofol level during the hypothermic period. Rewarming during $\mathrm{CPB}$ caused a gradual decline to prebypass plasma propofol concentration. These differences may have been caused by the different sampling sites (radial artery versus bypass oxygenator), acute haemodilution with a crystalloid pump prime, lack of redistribution of propofol from tissues into blood and the physiological changes that result from the onset of bypass.

As alluded to in the previous section, prolonged in fusion of propofol may have clinical implications once terminated. Bailie et al. ${ }^{24}$ recruited 12 patients requiring long-term sedation for mechanical ventilation. Propofol infusion lasted for a mean duration of $85.6 \mathrm{hr}$ at a mean rate of $2.58 \mathrm{mg} \cdot \mathrm{kg}^{-1} \cdot \mathrm{hr}^{-1}$. After termination of the infusion, propofol blood concentrations declined rapidly with an overall mean decrease of $50 \%$ over the first ten minutes. Albanese et al., ${ }^{25}$ for a 72 -hr propofol infusion at $3 \mathrm{mg} \cdot \mathrm{kg}^{-1} \cdot \mathrm{min}^{-1}$, showed that the plasma concentration decreased by $50 \%$ in six of the nine patients within the first ten minutes. According to the theoretical model proposed by Hughes et al. ${ }^{26}$ of context-sensitive half-time, they predicted that propofol plasma concentration, at steady state, would decrease by $50 \%$ after approximately $50 \mathrm{~min}$. Clearly, there is some discrepancy between this theoretical model predicting a 50\% decrease in plasma concentration and the concrete findings by Bailie $e t$ al. and Albanese et al. One possible explanation may relate to the propofol pharmacokinetic values used to derive the context-sensitive half-time.

\section{Pharmacodynamic behaviour}

\section{Haemodynamic effects}

The cardiovascular depressant properties of propofol appear to be similar to or greater than those of barbiturates. Mackenzie and Grant ${ }^{27}$ compared propofol (2.5 $\left.\mathrm{mg} \cdot \mathrm{kg}^{-1}\right)$, methohexitone $\left(1.5 \mathrm{mg} \cdot \mathrm{kg}^{-1}\right)$ and thiopentone ( $5 \mathrm{mg} \cdot \mathrm{kg}^{-1}$ ) in unpremedicated ASA I and II patients undergoing minor urological surgery. Compared with the methohexitone group, the propofol group had more patients who showed $>20 \%$ decrease in systolic blood pressure although all agents increased heart rate (HR) by the same percentage. In another comparative study in 96 ASA I patients, methohexitone and propofol increased cardiac index (CI) measured by pulsed 
Doppler ultrasound) while etomidate depressed CI by $16 \%{ }^{28}$ Thiopentone had no effects on $\mathrm{Cl}$ and systemic vascular resistance (SVR). Methohexitone and propofol decreased SVR by an average of $20 \%$ while etomidate caused a $12 \%$ increase in SVR. Claeys et al ${ }^{29}$ studied the haemodynamic effects of propofol, given as a single dose of $2 \mathrm{mg} \cdot \mathrm{kg}^{-1}$ and followed immediately by a continuous infusion of $6 \mathrm{mg} \cdot \mathrm{kg}^{-1} \cdot \mathrm{hr}^{-1}$ in ten elderly ASA II or III patients breathing room air spontaneously. Decreases in systolic and diastolic arterial pressures were observed two minutes after induction ( $28 \%$ and $19 \%$ respectively) and during infusion (30\% and $25 \%$ ) and were related to a $21 \%$ decrease in SVR. Cardiac output (CO), HR and stroke volume (SV) remained unaffected throughout the study period. Carlier et al..$^{30}$ showed that, in the absence of $\mathrm{N}_{2} \mathrm{O}$, systemic blood pressures decreased by $20 \%, \mathrm{CO}$ and SV by $22 \%$ while HR and SVR remained unchanged after $2.5 \mathrm{mg} \cdot \mathrm{kg}^{-1}$ propofol. Addition of $\mathrm{N}_{2} \mathrm{O}$ did not alter any haemodynamic variables. Similar haemodynamic findings to that of Carlier $e t$ al.$^{30}$ have been reported in ASA I-III patients. ${ }^{14,31}$ The discrepancies between these latter studies and that by Claeys et al. ${ }^{29}$ may well reside in their respective study protocols. As suggested by Carlier et al. ${ }^{30}$ patients in Claeys' study had a greater increase in $\mathrm{PaCO}_{2}$ i.e., respiratory acidosis. This respiratory acidosis may have masked some cardiodepressive effects of propofol.

The haemodynamic response to $0.0,0.25,0.50,0.75$ and 1.0 MAC isoflurane administered in a random fashion concurrently with a constant propofol infusion in normocapnic ASA I and II patients, demonstrated a dosedependent decrease in mean arterial pressure while $\mathrm{CO}$, SV and HR were not affected. ${ }^{32}$ Pulmonary capillary wedge pressure and central venous pressure were minimally altered, while intrapulmonary shunting and $\mathrm{PaO}_{2}$ remained constant.

\section{Peripheral vasodilatation}

A reduction in blood pressure following induction of anaesthesia is observed with most induction agents, including propofol. The mechanisms implicated in the cardiovascular effects of a drug are the result of a complex interaction between: (1) baroreflex activity (heart rate), (2) direct peripheral vasodilatation, (3) central sympathetic nervous system outflow, (4) myocardial contractility, and (5) the underlying pathophysiological state of the myocardium.

In vitro hepatic portal vein and aorta taken from rats were used to investigate the direct action of propofol on the vascular smooth muscle. ${ }^{33}$ Propofol caused a doserelated decrease of potassium-induced tone in both types of vessels. Portal veins required significantly lower propofol concentrations to produce similar changes than in the isolated aortic preparation. The possible interaction with endothelium-derived relaxing factor (EDRF) was also explored using endothelium-denuded rings from rat aorta and pulmonary artery rings in which EDRF/nitric oxide (NO) synthase was inhibited. ${ }^{34}$ Propofol caused vasodilatation in aortic and pulmonary artery rings, whereas thiopentone had no effect. Propofol seemed to induce direct vasodilatation with a gradual attentuation probably due to a decreased basal release of EDRF. Furthermore, indomethacin-treated rings showed potentiation of an endothelium-dependent vasoconstriction with thiopentone and produced a decrease in propofol-induced dilatation. These results are consistent with the induction of some cyclooxygenase vasodilating metabolites by propofol and thiopentone. The latter findings are in contrast to those of Chang and Davis, ${ }^{35}$ who found that vasodilatation produced by propofol is not endotheliumdependent but is likely to be due to blockade of voltagegated influx of extracellular calcium.

Rouby et al..$^{36}$ and Boer et al. ${ }^{37}$ demonstrated that propofol caused profound peripheral vascular dilatation that contributed to the decline in mean arterial blood pressure in patients whose $\mathrm{CO}$ was respectively controlled with artificial hearts or cardiopulmonary bypass. Muzi et al..$^{38}$ reported that propofol-induced hypotension also appeared to be mediated to a large extent by vasodilatation in human volunteers. Ebert et al. ${ }^{39}$ also reported reduced forearm vascular resistance in association with a $76 \%$ decrease in efferent sympathetic nervous activity with propofol while etomidate showed no change. Propofol in contrast to halogenated agents does not inhibit hypoxic pulmonary vasoconstriction in patients undergoing leftsided thoracotomy. ${ }^{40}$ These studies inferred that the haemodynamic depression observed with propofol could be attributed primarily to alterations in peripheral arterial and/or venous tone. Despite these well-designed studies, other investigators have found SVR to be unchanged, ${ }^{14,30,31,41}$ while Naeije et al ${ }^{42}$ reported that vascular tone was related to the concentration of oxygen. During hyperoxia, SVR was increased while the opposite occurred during hypoxaemia. Thus, depending on the concentration of oxygen used in the various studies, the effect on SVR of propofol may have been masked.

\section{Myocardial contractility}

The direct effects of propofol on myocardial contractility remain controversial despite extensive study. Several of these studies are summarized in Table I. Mulier et al..$^{43}$ and Gauss et al. ${ }^{44}$ used transoesophageal echocardiography to indirectly assess myocardial contractility. They reported that induction doses of propofol appeared to decrease inotropic state in ASA I and II patients. In halothane-anaesthetized swine, graded increase in plasma 


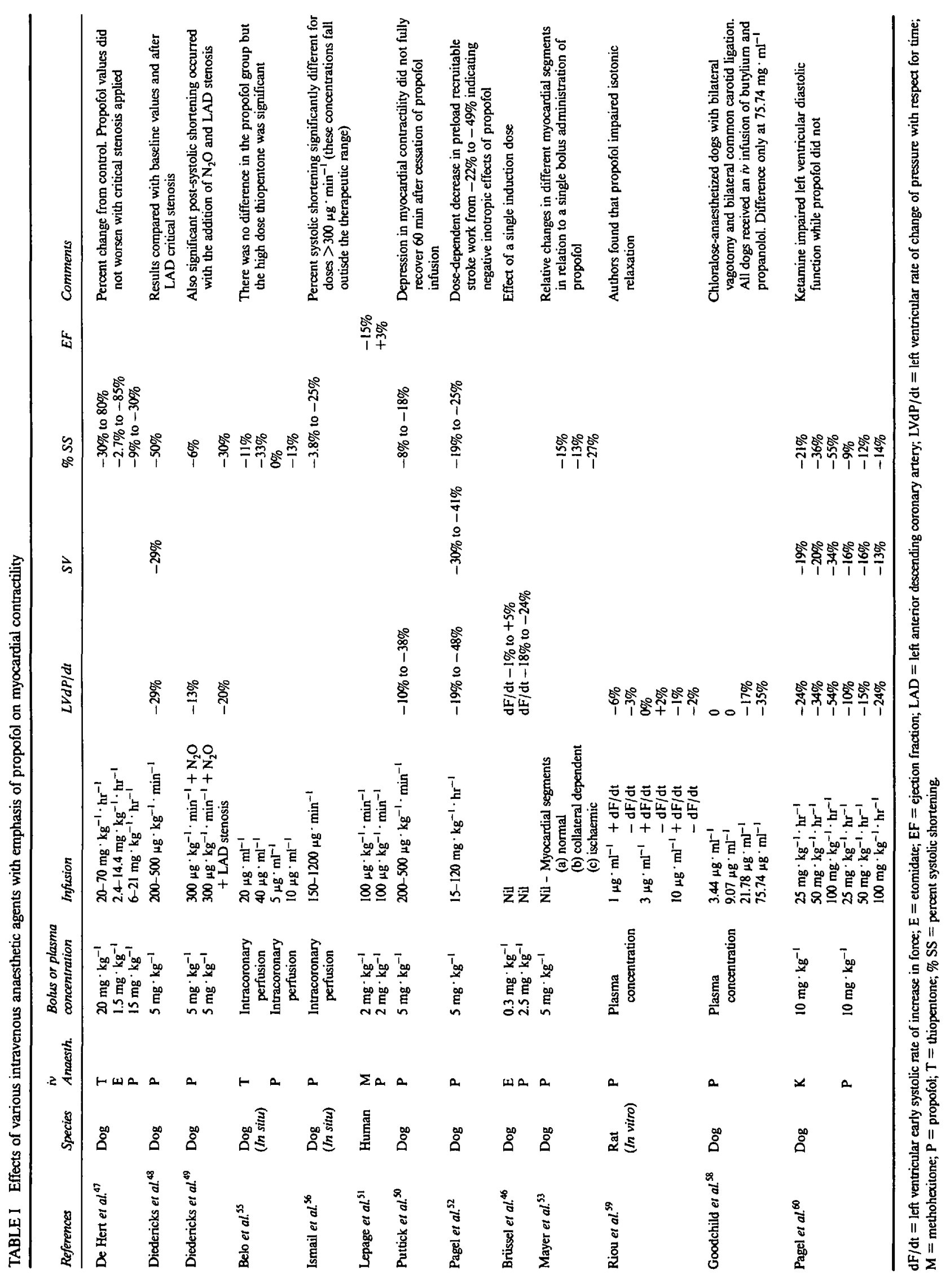


concentrations of propofol resulted in progressive decline in myocardial contractility. ${ }^{45}$ Similarly in ketamineanaesthetized mongrel dogs, propofol demonstrated an average $16.3 \%$ and $23.5 \%$ decrease in left ventricular force and early systolic rates of increase force $(\mathrm{dF} / \mathrm{dt})$ respectively while etomidate showed no change. ${ }^{46}$ As shown in Table I, several studies ${ }^{47-54}$ have provided evidence to support the contention that propofol-induced hypotension is mediated principally by depression of myocardial contractility, others have shown little effect in ventricular performance. ${ }^{55-59}$ There is one in vitro study that reported no alteration in left ventricular diastolic function with propofol, contrary to ketamine which caused, in a dosedependent fashion, left ventricular diastolic dysfunction. ${ }^{60}$

Animal models of critical coronary artery constriction have shown that all intravenous anaesthetic agents were associated with a dose-dependent decrease in end-diastolic length indicating a decrease in left ventricular filling pressure. ${ }^{47-50}$ Regional myocardial function in normal and ischaemic segments remained unaltered for etomidate, while thiopentone showed a dose-dependent decrease in systolic shortening in normal segment and worsening in ischaemic region. ${ }^{47}$ Propofol showed similar decrease in systolic shortening in normal myocardium but did not worsen in the ischaemic region. ${ }^{47}$ The latter report has not been substantiated; most report worsening of myocardial shortening with propofol. ${ }^{50,53}$ The addition of nitrous oxide during a basal infusion of propofol caused mild global myocardial depression but in the presence of a critical coronary stenosis, myocardial contractility was severely perturbed. ${ }^{49}$ Finally, the recovery of myocardial contractility in ischaemic segments did not parallel the decrease in plasma propofol concentration ${ }^{45}$ and persisted even after $60 \mathrm{~min}$ of recovery. ${ }^{50}$

\section{Baroreflex activity}

Haemodynamic responses to anaesthesia are related, at least in part, to the action of anaesthetic agents on sympathetic nervous system activity and on the baroreflex response. Most of these agents have a disruptive effect on these systems and responses which may disturb the adaptive responses in certain stressful circumstances. Several clinical studies have shown that propofol used alone for induction and/or maintenance of anaesthesia does not change baroreflex sensitivity as assessed by the change in the slope of the pressor and depressor curve, ${ }^{61-63}$ but a marked and sustained alteration of the baroreflex setpoint was observed, in such a way as to allow unchanged heart rate at lower arterial pressure.

However, Ebert et al. ${ }^{39}$ found that propofol depressed both pressor and depressor baroreflex responses, while etomidate did not. The heart rate following induction of anaesthesia was unchanged after etomidate, but after pro- pofol, the heart rate increased in response to a decrease in blood pressure. In the same study, the sympathetic neural outflow after etomidate was unchanged whereas after propofol the sympathetic vasoconstrictor outflow decreased. This suggests that the sympathetic inhibition that occurs during propofol administration may contribute to the hypotension. Propofol-mediated decreases in sympathetic activity, i.e., increased venous compliance, decreased afterload and myocardial contractility, might be the unifying mechanism that explains these various observations. This has been substantiated in another study which showed that propofol infusion depressed the baroreflex activity in a dose-dependent fashion with a delayed recovery following termination of infusion. ${ }^{64}$

The use of a vagolytic drug before propofol to prevent or limit the decrease in blood pressure has also been investigated. In one study, ${ }^{65}$ glycopyrolate produced no clinical benefit in preventing the decrease in blood pressure while Skues et al. ${ }^{66}$ showed, for a comparable increase in heart rate, that glycopyrolate-treated patients had a higher arterial blood pressure than those treated with atropine. The reason for the difference between glycopyrolate and atropine is unknown. Selective muscarinic $\left(\mathrm{M}_{1}\right)$ agonist stimulation can increase sympathetic ganglionic activity and thus increase blood pressure and glycopyrolate exerts an anticholinergic action through selective antagonism of $M_{2}$ leaving the $M_{1}$ receptor unopposed while atropine antagonizes both $M_{1}$ and $M_{2}$ receptors.

\section{Myocardial metabolism and blood flow}

In patients with known coronary artery disease, imbalance between myocardial oxygen supply and demand may result in intraoperative myocardial ischaemia and subsequent postoperative myocardial infarction. During cardiac surgery, tracheal intubation, sternotomy and sternal spread are the major physical stresses that may result in a haemodynamically related ischaemic response. ${ }^{67,68}$ Much controversy has surrounded the role of some anaesthetic agents in directly causing myocardial ischaemia.

The effect of propofol $\left(200 \mu \mathrm{g} \cdot \mathrm{kg}^{-1} \cdot \mathrm{min}^{-1}\right)$ as the sole anaesthetic or in combination with fentanyl (10 $\mu \mathrm{g} \cdot \mathrm{kg}^{-1}$ ) on myocardial blood flow and metabolism was investigated in patients undergoing coronary artery bypass surgery $(\mathrm{CABG}) .{ }^{69}$ Following induction of anaesthesia, mean arterial blood pressure was reduced by $15 \%$ along with a $19 \%$ and $25 \%$ decrease in cardiac index and stroke volume index respectively while heart rate increased by $18 \%$. Myocardial blood flow decreased by $26 \%$ in association with a $31 \%$ reduction in myocardial oxygen consumption. Surgical stimulation led to the return of haemodynamic variables toward baseline except for 
a further decrease in cardiac index. Myocardial lactate production was increased in only one patient. Combining a higher fentanyl dose $\left(30 \mu \mathrm{g} \cdot \mathrm{kg}^{-1}\right)$ with a constant propofol infusion (mean dosage $4.45 \mathrm{mg} \cdot \mathrm{kg}^{1} \cdot \mathrm{hr}^{-1}$ ) did not alter baseline coronary sinus blood flow, myocardial oxygen consumption and myocardial lactate extraction. ${ }^{70}$ In a comparative study between sufentanil-propofol and sufentanil-enflurane, the haemodynamic and myocardial metabolic profiles were similar apart from hypotension during induction of anaesthesia with the administration of the propofol bolus. ${ }^{71}$

\section{Electrophysiological action}

The sporadic reporting of severe bradycardia following the administration of propofol suggested that this anaesthetic may possess some activity on the cardiac conduction system. ${ }^{72,73}$ The direct effects of propofol on the sinoatrial node and atrioventricular conduction have been assessed in animal studies. ${ }^{74,75}$ The reduction of cytosolic calcium entry by propofol and the possible influence on the cytosolic calcium mobilization may contribute to the observed shortening of the duration of action potential and the negative inotropic effect of this anaesthetic. ${ }^{75}$ The effects of propofol on calcium currents appear to be similar to those of halothane.

In vitro experiments on isolated rabbit sinoatrial node preparation have shown that propofol had only small effects on atrial conduction at $10 \mu \mathrm{g} \cdot \mathrm{ml}^{-1}$, but that it reduced conduction drastically at $33 \mu \mathrm{g} \cdot \mathrm{ml}^{-1}$ and caused complete block at $100 \mu \mathrm{g} \cdot \mathrm{ml}^{-1} .{ }^{74}$ The effects of propofol on sinoatrial nodes (rabbits and guinea pigs) were relatively slight at the concentrations likely to be seen in clinical practice. ${ }^{74,75}$ In humans with rhythm or conduction disturbances (atrial fibrillation or supraventricular tachycardia), propofol modified sinus node automaticity via central parasympathetic process. These effects are more likely to occur during surgical procedures associated with vagal stimulation or when propofol is used with other drugs known to stimulate cholinergic activity. Since the bradycardia observed clinically is reversible by administration of atropine, it is probably due to a centrally mediated increase in vagal tone. Saarnivaara et al. $^{76}$ reported that methohexitone, propofol and midazolam all prolonged QTc in patients with a normal control QTc interval. Contrary to these results, the QTc interval in patients with a prolonged control QTc tended to be shortened only with midazolam, but was not worsened by propofol or methohexitone.

\section{Cerebral physiology and metabolism}

Measuring local cerebral glucose utilization in anatomically discrete regions of the rat brain in response to different doses of propofol showed a dose-dependent de- crease in overall mean local cerebral glucose utilization. ${ }^{77,78}$ Although all brain substructures were involved, forebrain structures showed greater sensitivity to the depressant action of propofol than did hindbrain regions. Furthermore, certain regions were assayed and demonstrated a 60 to $90 \%$ decrease in local cerebral glucose utilization. ${ }^{78}$ Upon cessation of propofol infusion, the majority of brain areas rapidly returned to normal glucose uptake and no alteration in the energy state was seen for the different infusion rates of propofol studied. ${ }^{77}$ Propofol anaesthesia reduced the glucose uptake in 35 regions of the rat brain and cervical spinal cord by approximately 40 to $70 \% .^{79}$ Thus, propofol produces metabolic responses similar to those of the barbiturates.

The effect of propofol on cerebral blood flow (CBF), the uptake of oxygen by the brain $\left(\mathrm{CMRO}_{2}\right)$ and on the response of the cerebral vasculature to $\mathrm{CO}_{2}$ in 11 patients prior to undergoing extracorporeal circulation has been evaluated ${ }^{80}$ Propofol caused a $24 \%$ and $17 \%$ decrease in mean arterial pressure and cardiac index respectively. Cerebral perfusion pressure (CPP) declined by $25 \%$ during normoventilation, increased by $8 \%$ with hyperventilation and decreased again by $12 \%$ after hypoventilation. During normocapnia, CBF decreased by $51 \%$ and was accompanied by a $55 \%$ increase in cerebrovascular resistance (CVR) and a 36\% decrease in $\mathrm{CMRO}_{2}$. Hyperventilation to a $\mathrm{PaCO}_{2}$ of $30 \mathrm{mmHg}$ caused a $43 \%$ increase in CVR and CBF decreased 25\% further while $\mathrm{CMRO}_{2}$ remained unchanged. Hypoventilation to a $\mathrm{PaCO}_{2}$ of $50 \mathrm{mmHg}$ was followed by a $67 \%$ increase in CBF, a $44 \%$ decrease in CVR and a $38 \%$ decrease in $\mathrm{CMRO}_{2}$. It can be assumed from these findings that the reactivity of the cerebral vessels to changes in $\mathrm{PaCO}_{2}$ is maintained during anaesthesia with propofol.

In a study of 23 patients without increased intracranial pressure (ICP), propofol, $1.5 \mathrm{mg} \cdot \mathrm{kg}^{-1}$, followed by an infusion, $100 \mu \mathrm{g} \cdot \mathrm{kg}^{-1} \cdot \mathrm{min}^{-1}$, decreased lumbar cerebral spinal fluid pressure (CSFP) by $37 \% .^{81,82}$ The CPP remained above $70 \mathrm{mmHg}$ despite a decrease in mean arterial pressure and CSFP. These values returned to baseline after tracheal intubation, application of pin holders and skin incision. As propofol increases CVR, the decrease in CSFP may be attributed to a decrease in cerebral blood volume. As with barbiturates, the response to propofol is transient, demonstrating its rapid redistribution and metabolism. When associated with a suitable opioid, propofol can obtund the CSFP and mean arterial pressure responses to intubation and noxious stimulation. Evaluation of propofol in patients with and without elevated CSFP has shown that the higher the CSFP, the greater the decrease in CSFP. ${ }^{82}$ However, during induction and after tracheal intubation, CSFP remains higher in patients with intracranial hypertension. When propo- 
fol, $2 \mathrm{mg} \cdot \mathrm{kg}^{-1}$, was administered over $90 \mathrm{sec}$ to six comatose patients with elevated ICP $>25 \mathrm{mmHg})$ it caused a decrease in ICP but also lowered CPP below $50 \mathrm{mmHg}$ in four patients. In another study on human brain retraction pressure (BRP), propofol reduced BRP by an average of $3.3 \mathrm{mmHg}$ but also caused a $22.9 \mathrm{mmHg}$ reduction in CPP. ${ }^{83}$

Kalkman et al. ${ }^{84}$ showed that propofol preserved the early posterior tibial nerve somatosensory cortical evoked potential peaks more than did a combination alfentanilnitrous-oxide. Propofol appears to have no effect on the time latencies of the brain stem auditory evoked potentials but showed attenuation in amplitude and increased latency of the cortical middle potential of the auditory response. ${ }^{85}$

Brain electrical activity, neurological outcome, and neuronal damage following incomplete ischaemia in rats showed that propofol improved neurological outcome and decreased neuronal damage compared with a group of rats receiving nitrous oxide and fentanyl. The cerebral protection of propofol was independent of plasma glucose concentration. ${ }^{86}$ These findings are in contrast to those of Weir et al. ${ }^{87}$ in cats, where propofol failed to improve the neuropathological outcome following incomplete ischaemia while improving post-ischaemic CBF, extracellular fluid acidosis, hyperkalaemia and a late improvement in calcium ion activity.

There are conflicting data with respect to the anticonvulsive properties of propofol. When propofol was titrated to achieve conscious sedation in 11 treated epileptic patients, six showed no change and five showed either a reduction in epileptic activities or complete suppression of the paroxystic discharges. ${ }^{88}$ Hufnagel et al. ${ }^{89}$ in 12 of 20 epileptic patients, observed maximal suppression of brain activity in the epileptogenic areas with ten patients showing suppression of spontaneous interictal activity, but in five patients induction of epileptiform activity was generated with only one patient convulsing. Several studies have shown that propofol shortens the duration of seizures in patients undergoing electroconvulsive therapy ${ }^{90.91}$ Experiments carried out in rodents to assess the protection afforded by propofol and thiopentone against induced epileptiform seizures showed that both anaesthetic drugs were effective at sedative doses. ${ }^{92,93}$ In an animal model of induced status epilepticus, bolus administration of propofol followed by an infusion completely suppressed electrical and clinical seizures in rabbits. This suggests that propofol may be useful in patients with status epilepticus when other agents have failed. ${ }^{94,95}$

\section{Respiration}

Induction and maintenance of anaesthesia with propofol alters many respiratory variables. Several investiga- tions have focused on the frequency and duration of apnoea following an induction dose of propofol. Apnoea for longer than $60 \mathrm{sec}$ and a decrease in respiratory rate were observed more frequently after propofol than after thiopentone or methohexitone. ${ }^{96}$ The incidence of apnoea seemed to be influenced by the state of hyperventilation or hyperoxia prior to induction since the incidence was $96 \%$ after breathing $100 \%$ oxygen and only $68 \%$ after breathing room air. ${ }^{97}$ Furthermore, the duration of apnoea was twice as long in patients breathing $100 \%$ oxygen. During hypoxic and hypercapnic challenge, propofol had a greater depression of the afferent chemoreceptor acivity compared with thiopentone and etomidate. ${ }^{98}$

Minute ventilation, tidal volume, mean inspiratory flow rate and functional residual capacity are all decreased during propofol anaesthesia. ${ }^{99,100}$ During maintenance of anaesthesia, propofol may also depress the hypercapnic or ventilatory drive. Allsop et al. ${ }^{101}$ showed that in unpremedicated and papaveretum premedicated patients minute ventilation was depressed and a shift to the right of the carbon dioxide curve was present in both groups. Unpremedicated patients showed no change in the slope of their hypercarbic drive while the papaveretum group had a decrease in the carbon dioxide response to only $55 \%$ of the awake value. Recent results have shown that in mechanically ventilated COPD patients, propofol induces bronchodilatation. ${ }^{102}$

The effects of a sedative-hypnotic dose of propofol to maintain conscious sedation or light sleep have not been shown to cause respiratory depression. ${ }^{103}$

\section{Premedication and dose of propofol}

In most clinical situations, propofol is used in combination with premedication, opioid analgesics or inhalational anaesthetics, and consequently the possibility of additive or synergistic effects on haemodynamic variables is of interest. ${ }^{104}$ In randomized non-blinded studies, the decrease of blood pressure by propofol was not modified by benzodiazepine and/or intramuscular opioids ${ }^{105}$ while previous intravenous administration of an opioid analgesic potentiated the hypotensive response of an induction dose of propofol. ${ }^{106}$

\section{Speed of injection}

Varying the speed of injection or infusion rate only increased induction time, reduced the incidence of apnoea and total dose administered in the slower infusion groups, while the reductions in systolic and diastolic blood pressures were similar. ${ }^{107-109}$ Satisfactory and reliable anaesthesia was obtained even if propofol was administered rapidly. In young and elderly patients, Peacock et al. ${ }^{110}$ showed that the cardiorespiratory effects of propofol were related to the dose administered and not to the rate of 
administration. Interestingly, in their study, induction of anaesthesia in both groups was achieved with smaller doses than had been recommended previously.

\section{Oxygen-free radical scavenging}

Oxygen-free radicals are highly reactive compounds causing peroxidation of lipids and proteins and are thought to play an important role in the pathogenesis of reperfusion abnormalities including myocardial stunning, irreversible injury, and reperfusion arrhythmias. Potential sources of free radicals during ischaemia and reperfusion have been identified in myocytes, vascular endothelium, and leukocytes. Free radicals cause injury to processes involved in regulation of the intracellular $\mathrm{Ca}^{++}$concentration. Inhibiting free radical accumulation during myocardial ischaemia/reperfusion with free radical scavengers and inhibitors reduced the severity of myocardial stunning, irreversible injury, and reperfusion arrhythmias in many, but not all, studies. "II Propofol has free radical scavenging properties resembling those of the endogenous antioxidant $\alpha$-tocopherol (vitamin E). ${ }^{112}$ Its antioxidant activity has been shown in rat liver microsomes and mitochondria at blood concentration seen during clinical anaesthesia or sedation. ${ }^{113}$

Propofol also inhibits the activity of glutamate in the synaptosomes of rat brain. ${ }^{114}$ This causes inhibition of calcium influx in neurons which may offer effective protection against ischaemic or hypoxic injury that may occur during cardiopulmonary bypass. ${ }^{115}$ These properties of propofol offer theoretical advantages to its use in neuro and cardiac anaesthesia, particularly since free radical mediated tissue injury may contribute to many disease processes.

\section{The immune response}

Some anaesthetic agents may inhibit various immune functions but because they are usually administered for a short time, their effects are generally short-lived and reversible. However, this may be relevant if the agent is administered continuously for several days as might be seen in the ICU.

At anaesthetic concentrations, propofol and thiopentone produced $50 \%$ inhibition in neutrophil polarization, which is a structural change of neutrophils induced after chemotactic challenge by bacteria. ${ }^{116}$ Complete inhibition could be attained with higher concentrations. Midazolam produced no effect at clinically tested concentrations. The lipid carrier alone (10\% Intralipid) increased neutrophil polarization. Human serum albumin confers some degree of protection at normal propofol concentrations but failed to do so at high concentrations. In another in vitro study, random and chemotactic stimulated locomotion of human neutrophils were adversely affected at clinical con- centrations. ${ }^{117}$ Although these experiments were carried out in vitro, they indicate that inhibition of the immune response may have serious repercussions if the agent is administered continuously to patients with known infection or to immunocompromised patients. Aseptic techniques must be applied to the handling of the drug. Propofol contains no antimicrobial preservatives and the vehicle supports the growth of micro-organisms. Asepsis must be maintained throughout the infusion period but no established guidelines for changing $i v$ tubing and/or solution are available except those for administration of Intralipid.

\section{Coagulation}

Because fat emulsions may alter coagulation and fibrinolysis there is concern over the short- and long-term use of propofol. ${ }^{118,119}$ At present, short-term use of the emulsion formulation has not shown any haematological changes even in the presence of nitrous oxide. ${ }^{120}$ Very few studies have addressed this issue in the context of prolonged infusion. In one postoperative sedation study, an increase in prothrombin time (18 to $19.4 \mathrm{sec}$ ) was reported in ten critically ill patients eight hours after stopping the infusion ${ }^{121}$ while no change in prothrombin time, platelet count or fibrinogen concentration was seen after four days of propofol infusion in 14 agitated patients requiring sedation for mechanical ventilation. ${ }^{122}$ Patients in the former study had other underlying conditions that may have contributed to their already abnormal prothrombin time. More studies on prolonged infusion are needed especially in area where platelet dysfunction may occur, i.e., following cardiac surgery and in the ICU.

\section{Allergic reactions}

The previous formulation of propofol in Cremophor EL was associated with an unacceptable incidence of pain on injection and anaphylactoid reactions. The administration of the new emulsified preparation may produce skin flushing but is not associated with increases in plasma histamine, immunoglobulin or complement $\mathrm{C}_{3}$ concentrations. ${ }^{123}$ In vitro testing of ketamine, thiopentone and propofol failed to reduce, in human basophils, the release of histamine and de novo synthesis of leukotriene $\mathrm{C}_{4}$ but propofol induced release of histamine from mast cells derived from skin and lung origin but not from heart. ${ }^{124}$ In another in vitro study using basophils from normal and atopic patients, Laxenaire $e t$ al. ${ }^{125}$ showed a slightly higher incidence of histamine release from atopic patients for propofol, thiopentone and chlormethiazole but at much higher than clinical concentrations. Inevitably, reports of allergic reactions occurred with increased use. Initial reporting came from Europe $^{126,127}$ and now from the American continent. ${ }^{128}$ 
Recently 14 patients who had a life-threatening reaction following propofol exposure (either alone or in combination with other drugs) were investigated within 4-6 wk of their incident. ${ }^{129}$ Three different immunological tests were carried out: (1) skin testing to propofol and the solvent Intralipid, (2) leucocyte histamine release test and (3) radioimmunoassay of immunoglobulin $E$ to propofol and to muscle relaxant. Results identified 13 of 14 patients who had at least one positive test supporting hypersensitivity to propofol. Nine of 14 patients reported previous allergic histories (atopy, allergic reaction to either antibiotics, lidocaine, muscle relaxants or colloid).

Patients with known allergic reaction to eggs are generally allergic to egg protein or albumin and not to lecithin (the egg phosphatides which are present in the emulsion propofol). Unfortunately, patients are generally unable to discern to which egg protein they are allergic. Until more information is available, it would be prudent to avoid using propofol in these patients.

\section{Clinical Use}

\section{Cardiac anaesthesia}

The combination of propofol with an appropriate opioid in patients undergoing $\mathrm{CABG}$ reduced cardiac work while coronary blood flow and myocardial lactate extraction remained unchanged. ${ }^{70,71}$ However, even with smaller boluses of propofol $\left(1 \mathrm{mg} \cdot \mathrm{kg}^{-1}\right)$ at induction during $\mathrm{CABG}$, occasional severe reductions in arterial pressure were observed ${ }^{130}$ and myocardial lactate extraction was decreased in one patient. ${ }^{69}$ Using a similar propofol induction dose, preceded by $8 \mu \mathrm{g} \cdot \mathrm{kg}^{-1}$ of fentanyl, Vermeyen et al. ${ }^{131}$ noted a mean reduction in systolic blood pressure of $28 \%$ combined with a $25 \%$ reduction in SVR. Although no evidence of ischaemia was seen, a reduction of blood pressure of this magnitude may be hazardous. The authors speculated that the haemodynamic response may be related to the bolus administration overshooting target blood concentration. Utilizing a different administration protocol to achieve a plasma propofol concentration of $3 \mu \mathrm{g} \cdot \mathrm{ml}^{-1}$ rapidly without overshooting blood concentration, Roberts et al. ${ }^{132}$ did not observe any reduction in the haemodynamic variables. When the latter regimen was preceded by $3 \mu \mathrm{g} \cdot \mathrm{kg}^{-1}$ of fentanyl, this prevented any haemodynamic response to tracheal intubation. Russell et al. ${ }^{23}$ followed a standard cardiac induction technique (fentanyl $25 \mu \mathrm{g} \cdot \mathrm{kg}^{-1}$ and diazepam $0.1 \mathrm{mg} \cdot \mathrm{kg}^{-1}$ ) with a two-stage infusion of propofol to maintain anaesthesia. Ten minutes before skin incision propofol was started $\left(10 \mathrm{mg} \cdot \mathrm{kg}^{-1} \cdot \mathrm{hr}^{-1}\right)$ and continued for 15-20 min after sternal spread and then reduced to $3 \mathrm{mg} \cdot \mathrm{kg}^{-1} \cdot \mathrm{hr}^{-1}$ until the end of surgery. This regimen afforded excellent haemodynamic stability throughout surgery. Using a low-dose infusion of propofol to achieve a plasma concentration of $1 \mu \mathrm{g} \cdot \mathrm{ml}^{-1}$, in association with alfentanil for induction and maintenance of anaesthesia, afforded comparable haemodynamic stability. ${ }^{133}$ One must remember that this plasma concentration of propofol stands at the threshold value where patients are expected to emerge from anaesthesia.

The absence of explicit recall (the deliberate recollection of an experience) for intraoperative events does not preclude learning process during general anaesthesia. ${ }^{134}$ Bethune et al. ${ }^{135}$ in CABG patients, tested for implicit recall (the influence of a response by recall of a previous experience without remembering being influenced) during infusion of propofol or methohexitone as an hypnotic supplement to opioid-based anaesthetic. Patients were exposed to an auditory tape throughout the surgery and immediate postoperative period. No patients had explicit recall of any events during the surgery. The propofol group who heard the tape during the surgery had significant implicit recall which was absent in the methohexitone group. This confirms that auditory perception can occur during clinical anaesthesia, and that suppression of auditory awareness or learning is a function of both the degree of sedation and of surgical stimulation. Unfortunately, blood plasma concentrations of propofol or methohexitone were not determined and the propofol infusion seemed to be low, i.e., $2 \mathrm{mg} \cdot \mathrm{kg}^{-1} \cdot \mathrm{hr}^{-1}$ (33 $\left.\mu \mathrm{g} \cdot \mathrm{kg}^{-1} \cdot \mathrm{min}^{-1}\right)$.

Overall, the use of a propofol infusion, combined with a moderate dose of fentanyl, for the maintenance of anaesthesia during cardiac surgery provided good control of haemodynamic variable. To date, in patients with good left ventricular function, weaning from $\mathrm{CPB}$ with this technique does not appear to be a problem. Aside from reducing SVR during $\mathrm{CPB},{ }^{37}$ there are no data linking $\mathrm{CPB}$ pressure and propofol plasma concentrations. Myocardial contractility has been addressed earlier (see Myocardial contractility).

Cardiac surgical patients traditionally occupy highdependency beds in the ICU for up to $48 \mathrm{hr}$ because of lingering effects of $\mathrm{CPB}$, anaesthesia and intense postoperative sedation and this is expensive. When propofol anaesthesia was used during CPB and maintained until haemodynamic stability and bleeding stopped, only $7 \%$ of 245 cardiac patients required ICU admission. ${ }^{136}$ All these patients were brought initially to the recovery room and the average time for tracheal extubation was two hours from the time of arrival. Only those with persistent bleeding and/or haemodynamic instability were admitted to ICU, the remaining $93 \%$ were discharged to the ward the day of the operation. Thus, propofol anaesthesia combined with an appropriate opioid may prove to be very cost-effective. 
TABLE II Propofol for postoperative sedation

\begin{tabular}{|c|c|c|c|c|c|c|c|c|}
\hline References & $n$ & Agent & Patients & $\begin{array}{l}\text { Satisfactory } \\
\text { level of } \\
\text { sedation (\%) }\end{array}$ & $\begin{array}{l}\text { Spontaneous } \\
\text { ventilation } \\
\text { (min) }\end{array}$ & $\begin{array}{l}\text { Tracheal } \\
\text { extubation } \\
\text { (min) }\end{array}$ & $\begin{array}{l}\text { Amount of } \\
\text { analgesic }\end{array}$ & Comments \\
\hline Grounds et al. ${ }^{100}$ & $\begin{array}{l}30 \\
30\end{array}$ & $\begin{array}{l}\mathbf{M} \\
\mathbf{P}\end{array}$ & $\begin{array}{l}\text { Post-CABG } \\
\text { Post-CABG }\end{array}$ & $\begin{array}{l}81 \\
91\end{array}$ & $\begin{array}{l}197 \pm 22.5 \\
13.6 \pm 2.7\end{array}$ & $\begin{array}{l}226.1 \pm 22.8 \\
24.9 \pm 2.9\end{array}$ & $\begin{array}{l}15.9 \pm 2.1 \\
5.7 \pm 1.36\end{array}$ & $\begin{array}{l}\text { Propofol was superior in all } \\
\text { categories and less } \\
\text { papaveretum was used }\end{array}$ \\
\hline Snellen et $a l^{144}$ & $\begin{array}{l}20 \\
20\end{array}$ & $\begin{array}{l}\mathrm{M} \\
\mathbf{P}\end{array}$ & $\begin{array}{l}\text { Post-CABG } \\
\text { Post-CABG }\end{array}$ & $\begin{array}{l}53 \\
59.6\end{array}$ & $\begin{array}{l}66 \pm 16 \\
24 \pm 7\end{array}$ & $\begin{array}{l}243 \pm 44 \\
154 \pm 33\end{array}$ & & $\begin{array}{l}\text { Patients receiving propofol } \\
\text { needed more supplementary } \\
\text { doses and increments of } \\
\text { infusion rate }\end{array}$ \\
\hline McMurray et al. ${ }^{145}$ & $\begin{array}{l}50 \\
50\end{array}$ & $\begin{array}{l}M \\
P\end{array}$ & $\begin{array}{l}\text { Post-CABG } \\
\text { Post-CABG }\end{array}$ & $\begin{array}{l}56 \\
86\end{array}$ & & $\begin{array}{l}127.9 \pm 9.9 \\
11.9 \pm 2.5\end{array}$ & $\begin{array}{l}\text { Morphine } \\
0.72 \mathrm{mg} \cdot \mathrm{kg}^{-1} \\
0.57 \mathrm{mg} \cdot \mathrm{kg}^{-1}\end{array}$ & $\begin{array}{l}\text { Propofol group was superior } \\
\text { to midazolam in all categories }\end{array}$ \\
\hline Aitkenhead el al..$^{146}$ & 47 & M & $\begin{array}{l}\text { Critically ill } \\
\text { patients } \\
\text { Critically ill } \\
\text { patients }\end{array}$ & 94 & & $5(n=21)$ & & $\begin{array}{l}\text { Results of tracheal extubation } \\
\text { only available from } 39 \\
\text { patients }\end{array}$ \\
\hline
\end{tabular}

$\mathrm{M}=$ midazolam; $\mathrm{P}=$ propofol.

\section{Sedation in intensive care}

Most patients transferred from the operating room after $\mathrm{CABG}$ or major surgery are hypothermic and vasoconstricted. Those patients require ventilation and sedation for a limited time. The sedative technique must be reliable and allow a rapid and full recovery. The technique chosen should maintain a constant level of sedation, yet one which is readily adjustable without haemodynamic side effects.

In the ICU, satisfactory sedation can be achieved reliably and safely using either sedatives or hypnotics. The ideal sedative drug must provide a fast and smooth onset; an adjustable depth and predictable duration of sedation; be free of side effects; provide a pleasant recovery without rebound sedation. These pharmacodynamic requirements depend on such pharmacokinetic characteristics as: (1) a small initial volume of distribution, (2) a short contextsensitive half-time, (3) a high plasma clearance and (4) inactive metabolites.

The efficacy and dependability of propofol infusion for prolonged sedation has been reported (Table II). ${ }^{100,121,122}$ The advantages of propofol are: (1) satisfactory level of sedation with minimal adjustment in the infusion rate, (2) adequate level of sedation reached rapidly, (3) cumulative effects, tachyphylaxis or other untoward effects are not observed, (4) recovery time and rate of decrease in blood propofol concentration after $24-96 \mathrm{hr}$ of infusion are unchanged, (5) less analgesic was consumed, and (6) quicker return of spontaneous ventilation and more rapid tracheal extubation than after midazolam.
The mood-altering and psychomotor effects of propofol have been investigated in ten volunteers. ${ }^{137}$ Propofol produced mood alteration in a dose-dependent fashion that persisted for $30 \mathrm{~min}$ after termination of the infusion. Only with the high-dose propofol infusion were the psychomotor functions and anterograde amnesia impaired.

Most studies, using a prolonged infusion of propofol, did not show inhibition of adrenal steroidogenesis or cause any clinically important changes in the plasma lipid profile. There has been one report following four days of propofol administration where the urine turned green. ${ }^{138}$ Green urine is a well-known effect of phenols but the discoloration does not affect renal function.

Presently, the possibility of withdrawal phenomenon following the prolonged use of propofol has been raised in several case reports and in patients with a history of substance abuse. ${ }^{139}$ This phenomenon will have to be investigated by more detailed studies.

\section{Cardioversion}

Cardioversion under propofol causes more hypotension and apnoea but with a faster recovery and quicker orientation with a greater acceptance by the patient (more pleasant feeling) ${ }^{140}$ than after etomidate. The latter provided more haemodynamic stability but had serious drawbacks such as myoclonus, which interfered with the ECG interpretation, and the possibility of recall. ${ }^{141}$ Midazolam showed a longer induction time and delayed recovery with considerable inter-individual variability. ${ }^{142}$ Thiopentone was satisfactory although recovery was somewhat delayed 
compared with propofol in most studies, ${ }^{140,141}$ but it was faster in one study. ${ }^{143}$

\section{Summary}

Propofol has proved to be a reliable anaesthetic agent that can be used safely for induction and maintenance of anaesthesia for most surgical procedures and, unlike other agents, it can also be used for an adjustable sedation in the postoperative and/or intensive care settings. Clinical trials of propofol infusion with an appropriate opioid have been evaluated in special groups such as cardiac patients and produces similar haemodynamic results as high-dose opioid anaesthesia. Furthermore, propofol's evanescent action may enable the degree of sedation to be controlled more accurately and recovery of full consciousness to be achieved more quickly than with other intravenous anaesthetic agents. This has particular relevance in the management of patients after cardiac or neurological surgery, bumed patients and for restless patients requiring mechanical ventilation. Overall, comparative studies have demonstrated that propofol is at least as effective as other intravenous anaesthetics with potential advantages and disadvantages in individual situations.

The rapid, clear emergence and the lack of cumulative effects even after prolonged anaesthesia are its greatest features. The disadvantages include a relatively high incidence of short-lived apnoea, respiratory depression and blood pressure reduction that may occasionally be marked. However, the magnitude of these effects was such that their management was relatively straightforward in most cases. Other possible interactions with the immune, coagulation systems as well as allergic potential are summarized. Clinical data on its possible role in cerebral protection during CPB is not yet available other than its potential scavenging effect on the free radicals.

\section{Acknowledgements}

The authors would like to acknowledge the excellent secretarial work of Ms. Christiane Lussier and Mrs. Mary Morello.

\section{References}

1 Sebel PS, Lowdon JD. Propofol: a new intravenous anesthetic. Anesthesiology 1989; 71: 260-77.

2 Langley MS, Heel RC. Propofol. A review of its pharmacodynamic and pharmacokinetic properties and use as an intravenous anaesthetic. Drugs 1988; 35: 334-72.

3 Cockshott ID. Propofol (Diprivan) pharmacokinetics and metabolism - an overview. Postgrad Med J 1985; 61 (Suppl 3): 45-50.

4 Gepts E, Camu F, Cockshott ID, Douglas EJ. Disposition of propofol administered as constant rate intravenous infusions in humans. Anesth Analg 1987; 66: 1256-63.
5 Cockshott ID, Briggs LP, Douglas EJ, White M. Pharmacokinetics of propofol in female patients. Studies using single bolus injections. $\mathrm{Br} \mathrm{J}$ Anaesth 1987; 59: 1103-10.

6 Kay NH, Sear JW, Uppington J, Cockshott ID, Douglas EJ. Disposition of propofol in patients undergoing surgery. A comparison in men and women. Br J Anaesth 1986; 58: 1075-9.

7 Kirkpatrick T, Cockshot ID, Douglas EJ, Nimmo WS. Pharmacokinetics of propofol (Diprivan) in elderly patients. $\mathrm{Br} \mathrm{J}$ Anaesth 1988; 60: 146-50.

8 Campbell GA, Morgan DJ, Kumar K, Crankshaw DP. Extended blood collection period required to define distribution and elimination kinetics of propofol. $\mathrm{Br} \mathrm{J}$ Clin Pharmacol 1988; 26: 187-90.

9 White PF. Propofol: pharmacokinetic and pharmacodynamics. Seminars in Anesthesia 1988; 7 (Suppl 1): 4-20.

10 Servin $F$, Haberer JP, Cockshott ID, Farinotti $R$, Desmonts JM. Propofol pharmacokinetics in patients with cirrhosis. Anesthesiology 1986; 65: A554.

11 Veroli P, O'Kelly B, Bertrand F, Trouvin JH, Farinotti $R$, Ecoffey $C$. Extrahepatic metabolism of propofol in man during the anhepatic phase of orthotopic liver transplantation. Br J Anaesth 1992; 68: 183-6.

12 Morcos WE, Payne JP. The induction of anaesthesia with propofol (Diprivan) compared in normal and renal failure patients. Postgrad Med J 1985; 61 (Suppl 3): 62-3.

13 Kirvelä $M$, Olkkola $K T$, Rosenberg PH, Yli-Hankala A, Salmela $K$, Lindgren $L$. Pharmacokinetics of propofol and haemodynamic changes during induction of anaesthesia in uraemic patients. Br J Anaesth 1992; 68: 178-82.

14 Tauzin-Fin P, Vinçon G, Houdek MC, Demotes-Mainard $F$, Muscagorry JM. Pharmacocinétique du propofol injecté après hémodilution intentionnelle préopératoire. Ann Fr Anesth Réanim 1991; 10: 337-42.

15 Stephen $C R$. Risk factors and outcome in elderly patients: an epidemiologic study. In: Stephen CR, Assaf RAE (Eds.) Geriatric Anesthesia: Priniples and Practice. Boston: Butterworths, 1986: 345-62.

16 Gill SS, Wright EM, Reilly CS. Pharmacokinetic interaction of propofol and fentanyl: single bolus injection study. Br J Anaesth 1990; 65: 760-5.

17 Gepts E, Jonckheer K, Maes V, Sonck W, Camu F. Disposition kinetics of propofol during alfentanil anaesthesia. Anaesthesia 1988; 43 (Suppl): 8-13.

18 Simons PJ, Cockshott ID, Douglas EJ, Gordon EA, Hopkins $K$, Rowland $M$. Disposition in male volunteers of a subanaesthetic intravenous dose of an oil in water emulsion of 14C-propofol. Xenobiotica 1988; 18: 429-40.

19 Schüttler J, Stoeckel H, Schwilden H. Pharmacokinetic and pharmacodynamic modelling of propofol (Diprivan) in volunteers and surgical patients. Postgrad Med J 1985: 61 (Suppl 3): 53-4. 
20 Knell PJW, McKean JF. An investigation of the pharmacokinetic profile of propofol (Diprivan) after administration for induction and maintenance of anaesthesia by repeat bolus doses in patients having spinal anaesthetic block. Postgrad Med J 1985; 61 (Suppl 3): 60-1.

21 Shafer A, Doze VA, Shafer SL, White PF. Pharmacokinetics and pharmacodynamics of propofol infusions during general anesthesia. Anesthesiology 1988; 69: 348-56.

22 Massey NJA, Sherry KM, Oldroyd S, Peacock JE. Pharmacokinetics of an infusion of propofol during cardiac surgery. Br J Anaesth 1990; 65: 475-9.

23 Russell GN, Wright EL, Fox MA, Douglas EJ, Cockshott ID. Propofol-fentanyl anaesthesia for coronary artery surgery and cardiopulmonary bypass. Anaesthesia 1989; 44: 205-8.

24 Bailie GR, Cockshott ID, Douglas EJ, Bowles BJM. Pharmacokinetics of propofol during and after long term continuous infusion for maintenance of sedation in ICU patients. Br J Anaesth 1992; 68: 486-91.

25 Albanese J, Martin C, Lacarelle B, Saux P, Durand A, Gouin $F$. Pharmacokinetics of long-term propofol infusion used for sedation in ICU patients. Anesthesiology 1990; 73: 214-7.

26 Hughes MA, Glass PAS, Jacobs JR. Context-sensitive half-time in multicompartment pharmacokinetic models for intravenous anesthetic drugs. Anesthesiology 1992; 76 : 334-41.

27 Mackenzie N, Grant IS. Propofol (Diprivan) for continuous intravenous anaesthesia. A comparison with methohexitone. Postgrad Med J 1985; 61 (Suppl 3): 70-5.

28 Price $M L$, Millar $B$, Grounds $M$, Cashman $J$. Changes in cardiac index and estimated systemic vascular resistance during induction of anaesthesia with thiopentone, methohexitone, propofol and etomidate. Br J Anaesth 1992; 69: 172-6.

29 Claeys MA, Gepts E, Camu F. Haemodynamic changes during anaesthesia induced and maintained with propofol. Br J Anaesth 1988; 60: 3-9.

30 Carlier S, Van Aken H, Vandermeersch E, Thorniley $A$, Byttebier $G$. Does nitrous oxide affect the hemodynamic effects of anesthesia induction with propofol? Anesth Analg 1989; 68: 728-33.

31 Coates DP, Monk CR, Prys-Roberts $C$, Turtle $M$. Hemodynamic effects of infusions of the emulsion formulation of propofol during nitrous oxide anesthesia in humans. Anesth Analg 1987; 66: 64-70.

32 Verborgh $C$, Verbessen $D$, Camu $F$. Haemodynamic effects of isoflurane during propofol anaesthesia. $\mathrm{Br} \mathrm{J}$ Anaesth 1992; 69; 36-9.

33 Bentley GN, Gent JP, Goodchild CS. Vascular effects of propofol: smooth muscle relaxation in isolated veins and arteries. J Pharm Pharmacol 1989; 41: 797-8.

34 Park WK, Lynch C, Johns RA. Effects of propofol and thiopental in isolated rat aorta and pulmonary artery. Anesthesiology 1992; 77: 956-63.

35 Chang KSK, Davis RF. Propofol produces endotheliumindependent vasodilation and may act as a $\mathrm{Ca}^{2+}$ channel blocker. Anesth Analg 1993; 76: 24-32.

36 Rouby JJ, Andreev A, Léger $P$ et al. Peripheral vascular effects of thiopental and propofol in humans with artificial hearts. Anesthesiology 1991; 75: 32-42.

37 Boer F, Bovill JG, Ros P, Van Ommen H. Effect of thiopentone, etomidate and propofol on systemic vascular resistance during cardiopulmonary bypass. $\mathrm{Br} \mathrm{J}$ Anaesth 1991; 67: 69-72.

38 Muzi M, Berens RA, Kampine JP, Ebert TJ. Venodilation contributes to propofol-mediated hypotension in humans. Anesth Analg 1992; 74: 877-83.

39 Ebert TJ, Muzi M, Berens $R$, Goff D, Kampine JP. Sympathetic responses to induction of anesthesia in humans with propofol or etomidate. Anesthesiology 1992; 76 : 725-33.

40 Van Keer $L$, Van Aken $H$, Vandermeersch $E$, Vermaut $G$, Lerut $T$. Propofol does not inhibit hypoxic pulmonary vasoconstriction in humans. Journal of Clinical Anesthesia 1989; 1: 284-8:

41 Diedericks J, Foëx P, Sear JW, Puttick RM, Ryder WA. Haemodynamic effects of propofol infusion. A doseresponse study. Eur J Anaesthesiol 1990; 7: 338-9.

42 Naeije $R$, Lejeune P, Leeman M, Melot C, Deloof $T$. Effects of propofol on pulmonary and systemic arterial pressure-flow relationships in hyperoxic and hypoxic dogs. Br J Anesth 1989; 62: 532-9.

43 Mulier JP, Wouters PF, Van Aken H, Vermaut G, Vandermeersch $E$. Cardiodynamic effects of propofol in comparison with thiopental: assessment with a transesophageal echocardiographic approach. Anesth Analg 1991; 72 : 28-35.

44 Gauss $A$, Heinrich $H$, Wilder-Smith $O H G$. Echocardiographic assessment of the haemodynamic effects of propofol: a comparison with etomidate and thiopentone. Anaesthesia 1991; 46: 99-105.

45 Coetzee A, Fourie P, Coetzee $J$, et al. Effect of various propofol plasma concentrations on regional myocardial contractility and left ventricular afterload. Anesth Analg 1989; 69: 473-83.

46 Brüssel $T$, Theissen $J L$, Vigfusson $G$, Lunkenheimer PP, Van Aken $H$, Lawin $P$. Hemodynamic and cardiodynamic effects of propofol and etomidate: negative inotropic properties of propofol. Anesth Analg 1989; 69: 35-40.

47 De Her SG, Vermeyen KM, Adriaensen HF. Influence of thiopental, etomidate, and propofol on regional myocardial function in the normal and acute ischemic heart segment in dogs. Anesth Analg 1990; 70: 600-7.

48 Diedericks J, Foëx $P$, Sear JW, Ryder WA. Haemodynamic effects of propofol infusion: dose-response 
study in compromised canine hearts. Br J Anaesth 1989; 64: 393P

49 Diedericks J, Leone BJ, Sear JW, Foëx P, Ryder WA. Effect of nitrous oxide during basal propofol anaesthesia on myocardium with normal and critically restricted blood supply. Br J Anaesth 1989; 62: 224P

50 Puttick RM, Diedericks J, Sear JW, Glen JB, Fö̈x P, Ryder WA. Effect of graded infusion rates of propofol on regional and global left ventricular function in the dog. $\mathrm{Br} \mathrm{J}$ Anaesth 1992; 69: 375-81.

51 Lepage JYM, Pinaud ML, Helias JH, Cozian AY, Le Normand $Y$, Souron $R J$. Left ventricular performance during propofol or methohexital anesthesia: isotopic and invasive cardiac monitoring. Anesth Analg 1991; 73: 3-9.

52 Pagel PS, Warlier DC. Negative inotropic effects of propofol as evaluated by the regional preload recruitable stroke work relationship in chronically instrumented dogs. Anesthesiology 1993; 78: 100-8.

53 Mayer $N$, Legat K, Weinstabl $C$, Zimpfer $M$. Effects of propofol on the function of normal, collateraldependent, and ischemic myocardium. Anesth Analg 1993; 76: 33-9.

54 Park WK, Lynch C 3rd. Propofol and thiopental depression of myocardial contractility. A comparative study of mechanical and electrophysiologic effects in isolated guinea pig ventricular muscle. Anesth Analg 1992; 74: 395-405.

55 Belo SE, Kolesar R, Mazer CD. Effect of intracoronary propofol on myocardial contractility in the dog. 14th Annual Meeting, Society of Cardiovascular Anesthesiologists 1992; 201.

56 Ismail EF, Kim SJ, Salem MR. Direct effects of propofol on myocardial contractility in in situ canine hearts. Anesthesiology 1992; 77: 964-72.

57 Khatib SY, Talafih KF, Takrouri MS. The hemodynamic effects of propofol on the isolated rabbit heart. Middle East Journal of Anaesthesia 1992; 11: 455-66.

58 Goodchild CS, Serrao JM. Cardiovascular effects of propofol in the anaesthetized dog. Br J Anaesth 1989; 63: 87-92.

59 Riou B, Besse $S$. Lecarpentier $Y$, Viars $P$. In vitro effects of propofol on rat myocardium. Anesthesiology 1992; 76: 609-16.

60 Pagel PS, Schmeling WT, Kampine JP, Warltier DC. Alteration of canine left ventricular diastolic function by intravenous anesthetics in vivo. Anesthesiolgy 1992; 76: 419-25.

61 Cullen PM, Turtle M, Prys-Roberts C, Way WL, Dye J. Effect of propofol anesthesia on baroreflex activity in humans. Anesth Analg 1987; 66: 1115-20.

62 Samain E, Marty J, Gauzit R et al. Effects of propofol on baroreflex control of heart rate and on plasma noradrenaline levels. Eur J Anaesthesiol 1989; 6: 321-6.

63 Blake DW, Jover B, McGrath BP. Haemodynamic and heart rate reflex responses to propofol in the rabbit. $\mathrm{Br} \mathrm{J}$ Anaesth 1988; 61: 194-9.

64 Kamijo Y, Goto H, Nakazawa K, Benson KT, Arakawa K. Arterial baroreflex attenuation during and after continuous propofol infusion. Can J Anaesth 1992; 39: 987-91.

65 Sneyd JR, Berry A. Effect of preinduction glycopyrrolate on the hemodynamic response to anesthesia with propofol. Anesth Analg 1991; 72: 831-4.

66 Skues MA, Richards MJ, Jarvis AP, Prys-Roberts C. Preinduction atropine or glycopyrrolate and hemodynamic changes associated with induction and maintenance of anesthesia with propofol and alfentanil. Anesth Analg 1989; 69: 386-90.

67 Slogoff $S$, Keats $A S$. Does perioperative myocardial ischemia lead to postoperative myocardial infarction? Anesthesiology $1985 ; 62$ : 107-14.

68 Mangano DT. Perioperative cardiac morbidity. Anesthesiology 1990; 72: 153-84.

69 Stephan H, Sonntag H, Schenk HD, Kettler D, Khambatta $H J$. Effects of propofol on cardiovascular dynamics, myocardial blood flow and myocardial metabolism in patients with coronary artery disease. Br J Anaesth 1986; 58 : 969-75.

70 Vermeyen KM, De Hert SG, Erpels FA, Adriaensen HF. Myocardial metabolism during anaesthesia with propofollow dose fentanyl for coronary artery bypass surgery. $\mathrm{Br} \mathrm{J}$ Anaesth 1991; 66: 504-8.

71 Hall RI, Murphy JT, Moffit EA, Landymore R, Pollak $P T$, Poole L. A comparison of the myocardial metabolic and haemodynamic changes produced by propofolsufentanil and enflurane-sufentanil anaesthesia for patients having coronary artery bypass graft surgery. Can $\mathbf{J}$ Anaesth 1991; 38: 996-1004.

72 Thomson SJ, Yate PM. Bradycardia after propofol infusion (Letter). Anaesthesia 1987; 42: 430.

73 Baraka A. Severe bradycardia following propofolsuxamethonium sequence. $\mathrm{Br} J$ Anaesth 1988; 61: 482-3.

74 Briggs I, Heapy CG, Pickering L. Electrophysiological effects of propofol on isolated sinoatrial node preparations and isolated atrial conduction in vitro. $\mathrm{Br} \mathbf{J}$ Pharmacol 1989; 97: 504-P.

75 Puttick RM, Terrar DA. Effects of propofol on membrane currents and contraction in single myocytes isolated from guinea-pig ventricle. Br J Pharmacol 1989; 98: 742P.

76 Saarnivaara L, Klemola UM, Lindgren L, Rautiainen P, Suvanto $A$. QT interval of the ECG, heart rate and arterial pressure using propofol, methohexital or midazolam for induction of anaesthesia. Acta Anaesthesiol Scand 1990; 34: 276-81.

77 Ori C, Dam M, Pizzolato G. Effetti del propofol (Diprivan) sull'attività funzionale cerebrale: correlazioni tra metabolismo, flusso ematico, attività elettrica e stato energetico tessutale. Acta Anesthesiologica Italica 1990; 41: 1-23. 
78 Dam $M$, Ori $C$, Pizzolato $G$, et al. The effects of propofol anesthesia on local cerebral glucose utilization in the rat. Anesthesiology 1990; 73: 499-505.

79 Cavazzuti M, Porro CA, Barbieri A, Galetti A. Brain and spinal cord metabolic activity during propofol anaesthesia. Br J Anaesth 1991; 66: 490-5.

80 Stephan $H$, Sonntag $H$, Schenk HD, Kohlhausen $S$. Effects of disoprivan on cerebral blood flow, cerebral oxygen consumption, and cerebral vascular reactivity. Anaesthesist 1987; 36: 60-5.

81 Ravussin P, Guinard JP, Ralley F, Thorin D. Effect of propofol on cerbrospinal fluid pressure and cerebral perfusion pressure in patients undergoing craniotomy. Anaesthesia 1988; 43: 37-41.

82 Ravussin P, Thorin D, Guinard JP, Freeman J. Effect of propofol on cerebro-spinal fluid pressure in patients with and without intracranial hypertension. J Drug Dev 1989; 2 (Suppl 2): 105-6.

83 Moss E, Price DJ. Effect of propofol on brain retraction pressure and cerebral perfusion pressure. $\mathrm{Br} \mathrm{J}$ Anaesth 1990; 65: 823-5.

84 Kalkman CJ, Traast H, Zuurmond WWA, Bovill JG. Differential effects of propofol and nitrous oxide on posterior tibial nerve somatosensory cortical evoked potentials during alfentanil anaesthesia. $\mathrm{Br} J$ Anaesth 1991; 66: 483-9.

85 Savoia $G$, Esposito C, Belfiore F, Amantea B, Cuocolo $R$. Propofol infusion and auditory evoked potentials. Anaesthesia 1988; 43: 46-9.

86 Kochs E, Hoffman WE, Werner C, Thomas C, Albrecht $R F$, Schulte am Esch $J$. The effects of propofol on brain electrical activity, neurologic outcome, and neuronal damage following incomplete ischemia in rats. Anesthesiology 1992; 76: 245-52.

87 Weir DL, Goodchild CS, Graham DI. Propofol: effects on indices of cerebral ischemia. Journal of Neurosurgical Anesthesiology 1989; 1: 284-9.

88 Oei-Lim VLB, Kalkman CJ, Bouvy-Berends ECM, et al. A comparison of the effects of propofol and nitrous oxide on the electroencephalogram in epileptic patients during conscious sedation for dental procedures. Anesth Analg 1992; 75: 708-14.

89 Hufnagel A, Elger CE, Nadstawek J, Stoeckel H, Böker $D K$. Specific response of the epileptic focus to anesthesia with propofol. Journal of Epilepsy 1990; 3: 37-45.

90 Bone ME, Wilkins CJ, Lew JK. A comparison of propofol and methohexitone as anaesthetic agents for electroconvulsive therapy. Eur J Anaesthesiol 1988; 5: 279-86.

91 Rampton AJ, Griffin RM, Stuart CS, Durcan $J J$, Huddy $N C$, Abbott MA. Comparison of methohexital and propofol for electroconvulsive therapy: effects on hemodynamic responses and seizure duration. Anesthesiology 1989; 70: 412-7.

92 Lowson S, Gent JP, Goodchild CS. Anticonvulsant prop- erties of propofol and thiopentone: comparison using two tests in laboratory mice. Br J Anaesth 1990; 64: 59-63.

93 Hasan ZA, Hasan MM, Al-Hader AA, Takrouri MS. The effect of propofol and thiopentone on pentylenetetrazol seizure threshold in the rat. Middle East Journal of Anesthesia 1992; 11: 359-67.

94 Wood PR, Browne GPR, Pugh S. Propofol infusion for the treatments of status epilepticus (Letter). Lancet 1988; I: 480-1.

95 Mackenzie SJ, Kapadia F, Grant IS. Propofol infusion for control of status epilepticus. Anaesthesia 1990; 45: 1043-5.

96 Gold MI, Abraham EC, Herrington C. A controlled investigation of propofol, thiopentone and methohexitone. Can J Anaesth 1987; 34: 478-83.

97 Thomson KD, Payne JP. Effect of oxygen on arterial saturation during induction of anaesthesia with propofol. $\mathrm{Br}$ J Anaesth 1987; 59: 1318P.

98 Ponte J, Sadler CL. Effect of thiopentone, etomidate and propofol on carotid body chemoreceptor activity in the rabbit and the cat. Br J Anaesth 1989; 62: 41-5.

99 Goodman NW, Black AMS, Carter JA. Some ventilatory effects of propofol as sole anaesthetic agent. $\mathrm{Br} \mathbf{J}$ Anaesth 1987; 59: 1497-503.

100 Grounds RM, Lalor JM, Lumley J, Royston D, Morgan $M$. Propofol infusion for sedation in the intensive care unit: preliminary report. BMJ 1987; 294: 397-400.

101 Allsop P, Taylor MB, Grounds RM, Morgan M. Ventilatory effects of a propofol infusion using a method to rapidly achieve steady-state equilibrium. Eur J Anaesthesiol 1988; 5: 293-303.

102 Conti $G$, Dell'Utri $D$, Vilardi V, et al. Propofol induces bronchodilation in mechanically ventilated chronic obstructive pulmonary disease (COPD) patients. Acta Anaesthesiol Scand 1993; 37: 105-9.

103 Rosa $G$, Conti G, Orsi P, et al. Effects of low-dose propofol administration on central respiratory drive, gas exchanges and respiratory pattern. Acta Anaesthesiol Scand 1992; 36: 128-31.

104 Ben-Shlomo I, Finger J, Bar-Av E, Perl AZ, Etchin A, Tverskoy $M$. Propofol and fentanyl act additively for induction of anaesthesia. Anaesthesia 1993; 48: 111-3.

105 Mc Collum JSC, Dundee JW. Comparison of induction characteristics of four intravenous anaesthetic agents. Anaesthesia 1986; 41: 995-1000.

106 Van Aken H, Meinshausen E, Prien T, Brüssel T, Heinecke $A$, Lawin $P$. The influence of fentanyl and tracheal intubation on the hemodynamic effects of anesthesia induction with propofol/ $\mathrm{N}_{2} \mathrm{O}$ in humans. Anesthesiology 1988; 68: 157-63.

107 Rolly G, Versichelen L, Huyghe L, Mungroop H. Effect of speed of injection on induction of anaesthesia using propofol. Br J Anaesth 1985; 57: 743-6. 
108 Stokes DN, Hutton P. Rate-dependent induction phenomena with propofol: implications for the relative potency of intravenous anesthetics. Anesth Analg 1991; 72: 578-83.

109 Peacock JE, Lewis RP, Reilly CS, Nimmo WS. Effect of different rates of infusion of propofol for induction of anaesthesia in elderly patients. $\mathrm{Br} \mathrm{J}$ Anaesth 1990; 65 : 346-52.

110 Peacock JE, Spiers SPW, McLauchlan GA, Edmondson $W C$, Berthoud M, Reilly CS. Infusion of propofol to identify smallest effective doses for induction of anaesthesia in young and elderly patients. Br J Anaesth 1992; 69: 363-7.

111 Goldhaber $J I$, Weiss $J N$. Oxygen free radicals and cardiac reperfusion abnormalities. Hypertension 1992; 20: 118-27.

112 Murphy PG, Myers DS, Davies MJ, Webster NR, Jones $J G$. The antioxidant potential of propofol (2,6-diisopropylphenol). Br J Anaesth 1992; 68: 613-8.

113 Musacchio E, Rizzoli V, Bianchi M, Bindoli A, Galzigna $L$. Antioxidant action of propofol on liver microsomes, mitochondria and brain synaptosomes in the rat. Pharmacol Toxicol 1991; 69: 75-7.

114 Bianchi M, Battistin T, Galzigna L. 2, 6-diisopropylphenol, a general anesthetic, inhibits glutamate action on rat synaptosomes. Neurochem Res 1991; 16: 443-6.

115 Siesjö BK, Bengtsson $F$. Calcium fluxes, calcium antagonists, and calcium-related pathology in brain ischemia, hypoglycemia and spreading depression: a unifying hypothesis. J Cerebr Blood Flow Metab 1989; 9: 127-40.

116 O'Donnell NG, McSharry CP, Wilkinson PC, Asbury AJ. Comparison of the inhibitory effect of propofol, thiopentone and midazolam on neutrophil polarization in vitro in the presence or absence of human serum albumin. $\mathrm{Br} \mathrm{J}$ Anaesth 1992; 69: 70-4.

117 Jensen AG, Dahlgren C, Eintrei C. Propofol decreases random and chemotactic stimulated locomotion of human neutrophils in vitro. Br J Anaesth 1993; 70: 99-100.

118 Burnham WR, Heptinstall S, Cockbill SR, Harrison S. Blood platelet behavior during infusion of an Intralipidbased intravenous feeding mixture. Postgrad Med J 1982; 58: 152-5.

119 Reid DI, Ingram GIL. Changes in blood coagulation during infusion of intralipid. Clin Sci 1967; 33: 339-42.

120 Sear JW, Uppington J, Kay NH. Haematological and biochemical changes during anaesthesia with propofol (Diprivan). Postgrad Med J 1985; 61 (Suppl 3): 165-8.

121 Newman LH, McDonald JC, Wallace PGM, Ledingham $I M C A$. Propofol infusion for sedation in intensive care. Anaesthesia 1987; 42: 929-37.

122 Beller JP, Pottecher T, Lugnier A, Mangin P, Otteni JC. Prolonged sedation with propofol in ICU patients: recovery and blood concentration changes during periodic interruptions in infusion. Br J Anaesth 1988; 61: 583-8.
123 Doenicke A, Lorenz W, Stanworth D, Duka T, Glen JB. Effects of propofol (Diprivan) on histamine release, immunoglobulin levels and activation of complement in healthy volunteers. Postgrad Med J 1985; 61: 15-20.

124 Stellato C, Casolaro V, Ciccarelli A, Mastronardi P, Mazzarella $B$, Marone $G$. General anaesthetics induce only histamine release selectively from human mast cells. $\mathrm{Br} \mathrm{J}$ Anaesth 1991; 67: 751-8.

125 Laxenaire $M C$, Mata $E$, Guéant $J L$, Moneret-Vautrin $D A$, Haberer JP. Basophil histamine release in atopic patients after in vitro provocation with thiopental, Diprivan ${ }^{\circledR}$ and chlormethiazole. Acta Anaesthesiol Scand 1991; 35: 706-10.

126 Laxenaire MC, Guéant JL, Bermejo E, Mouton C, Navez MT. Anaphylactic shock due to propofol (Letter). Lancet 1988; II: 739-40.

127 Laxenaire MC, Guéant $J L$, Moneret-Vautrin DA et al. Chocs anaphylactiques au propofol lors de la première utilisation. Ann Fr Anesth Réanim 1990; 9: R125.

128 de Leon-Casasola OA, Weiss A, Lema MJ. Anaphylaxis due to propofol. Anesthesiology 1992; 77: 384-6.

129 Laxenaire MC, Mata-Bermejo E, Moneret-Vautrin DA, Guéant $J L$. Life-threatening anaphylactoid reactions to propofol (Diprivan ${ }^{\circledR}$ ). Anesthesiology 1992; 77: 275-80.

130 Patrick MR, Blair IJ, Feneck RO, Sebel PS. A comparison of the haemodynamic effects of propofol (Diprivan) and thiopentone in patients with coronary artery disease. Postgrad Med J 1985; 61: 23-7.

131 Vermeyen KM, Erpels FA, Janssen LA, Beeckman CP, Hanegreefs $G H$. Propofol-fentanyl anaesthesia for coronary bypass surgery in patients with good left ventricular function. Br J Anaesth 1987; 59: 1115-20.

132 Roberts FL, Dixon J, Lewis GTR, Tackley RM, PrysRoberts $C$. Induction and maintenance of propofol anaesthesia. Anaesthesia 1988; 43: 14-7.

133 Manara AR, Monk CR, Bolsin SN, Prys-Roberts C. Total i.v. anaesthesia with propofol and alfentanil for coronary artery bypass grafting. Br J Anaesth 1991; 66: 716-8.

134 Griffiths $D$, Jones JG. Awareness and memory in anaesthetized patients (Editorial). Br J Anaesth 1990; 65: 603-6.

135 Bethune $D W$, Ghosh $S$, Gray B, et al. Learning during general anaesthesia: implicit recall after methohexitone or propofol infusion. Br J Anaesth 1992; 69: 197-9.

136 Chong JL, Pillai $R$, Fisher A, Grebenik $C$, Sinclair $M$, Westaby $S$. Cardiac surgery: moving away from intensive care. Br Heart J 1992; 68: 430-3.

137 Zacny JP, Lichtor JL, Coalson DW et al. Subjective and psychomotor effects of subanesthetic doses of propofol in healthy volunteers. Anesthesiology 1992; 76: 696-702.

138 Bodenham A, Culank LS, Park GR. Propofol infusion and green urine (Letter). Lancet 1987; 2: 740.

139 Follette JW, Farley WJ. Anesthesiologist addicted to propofol. Anesthesiology 1992; 77: 817-8. 
140 Valtonen $M$, Kanto $J$, Klossner $J$. Anaesthesia for cardioversion: a comparison of propofol and thiopentone. Can J Anaesth 1988; 35: 479-83.

141 Mitterschiffihaler $G$, Lechleitner P, Hauptlorenz $S$, Wencker $M$, Dienstl $F$. Anesthésie pour cardioversion. Comparaison du propofol et de l'étomidate. Cahiers d'Anesthésiologie 1990; 38: 159-63.

142 Canessa $R$, Lema G, Urzúa J, Dagnino J, Concha $M$. Anesthesia for elective cardioversion: a comparison of four anesthetic agents. J Cardiothorac Vasc Anesth 1991; 5: 566-8.

143 Sternlo JE, Hägerdal $M$. Anaesthesia for cardioversion clinical experiences with propofol and thiopentone. Acta Anaesthesiol Scand 1991; 35: 606-8.

144 Snellen $F$, Lauwers P, Demeyere $R$, Byttebier $G$, Van Aken $H$. The use of midazolam versus propofol for shortterm sedation following coronary artery bypass grafting. Intensive Care Med 1990; 16: 312-6.

145 McMurray TJ, Collier PS, Carson IW, Lyons Sm, Elliot P. Propofol sedation after open heart surgery. A clinical and pharmacokinetic study. Anaesthesia 1990; 45: 322-6.

146 Aitkenhead AR, Pepperman ML, Willats SM, et al. Comparison of propofol and midazolam for sedation in critically ill patients. Lancet 1989; II: 704-9. 